УДК 621.375.826:621

\title{
АВТОМАТИЗОВАНА УСТАНОВКА ДЛЯ ВИСОКОЯКІСНОї \\ ГАЗОЛАЗЕРНОӦ РІЗКИ МЕТАЛІВ ДЛЯ ПОТРЕБ ПОЛІГРАФІЧНИХ ВИРОБНИЦТВ
}

๔ В. В. Романенко, к.т.н., доцент, НТУУ «КПI», Київ, Україна

В данной работе на основе анализа возможных технологических схем газолазерной резки металлических материалов предложена автоматизированная установка такой обработки для нужд полиграфической промышленности, В которой оптимальное протекание процесса резки поддерживается за счет контроля положения струи выходящего из полости реза рабочего газа, что обеспечивает выполнение процесса резки с высоким качеством при максимально возможной производительности обработки.

In this work on the basis of analysis of possible technological charts of the gas-assisted laser cutting of metallic materials the automated fluidizer of such treatment for the necessities of polygraphy industry is offered in which the optimum flowing of cutting process is supported due to control of position of stream of going out from a cavity of cut of working gas, that provides implementation of cutting process with high quality at the maximally possible productivity of treatment.

\section{Постановка проблеми}

Лазерна різка різних металевих матеріалів завтовшки від 1 до 20 мм $з$ одночасною співвісною подачею допоміжного газового струменя в зону різки широко застосовується як в поліграфічній промисловості, так і в інших галузях сучасного виробництва. При цьому під час різки можуть виникати різноманітні нестабільності цього процесу такі, як коливання потужності лазерного променя, зміна умов його фокусування на різних віддаленнях від лазерного випромінювача, зміна товщини і властивостей (наприклад, відбивної здатності) металу, що розрізається. Тому важливо в процесі обробки в автоматизованому режимі коректувати режими різки для забезпечення необхідної якості кромок отримуваних деталей.

\section{Мета роботи}

Підвищення якості процесу газолазерної різки при його максимально можливій продуктивності в автоматизованому режимі при вирізуванні металевих деталей складного контура для потреб поліграфічної промисловості.

\section{Результати проведених досліджень}

Газолазерна різка металів за традиційною схемою викону- 
ється при постійній швидкості різки на режимах, що забезпечують задану якість процесу при максимально можливій продуктивності процесу [1]. Перебіг процесу різки при цьому дуже критичний до будь-яких коливань як параметрів обробки, так і характеристик заготовки. Тому важливо розробити автоматизований пристрій, що дозволяє забезпечити необхідну якість різу при максимальній продуктивності. Відомий автоматизований пристрій для регулювання якості обробки, що складається з проектора, освітлюючого ділянку отримуваного різу, і оптичного індикатора висоти шорсткостей з оптикоелектронною перетворюючою системою в сигнал, що управляє [2]. Цей пристрій дозволяє здійснювати безперервний контроль якості різки і, на підставі цього контролю, автоматично встановлювати оптимальну швидкість обробки. Проте пристрій є складним, громіздким і дорогим.

Розроблена автоматизована установка для газолазерної різки матеріалів (рис. 1) [3], що містить лазерний випромінювач 1 з поворотним дзеркалом 2. Лазерний промінь 3 фокусується лінзою 4 на поверхні заготовки 5. Робочий газ через патрубок подається в сопло 6 і співвісно лазерному променю поступає в зону різки. Знизу оброблюваної заготовки, встановленої на робочому столі 7 з механізмом його приводу 8, безпосередньо під різом, розташовані два датчики тиску 9 і 10. Датчик 9 встановлений на відстані, рівній радіусу сфокусованого лазерного променя від його осі в напрямку, протилежному до напрямку різки, а датчик 10 зміщений по відношенню до першого в тому ж напрямку на відстань d, рівну

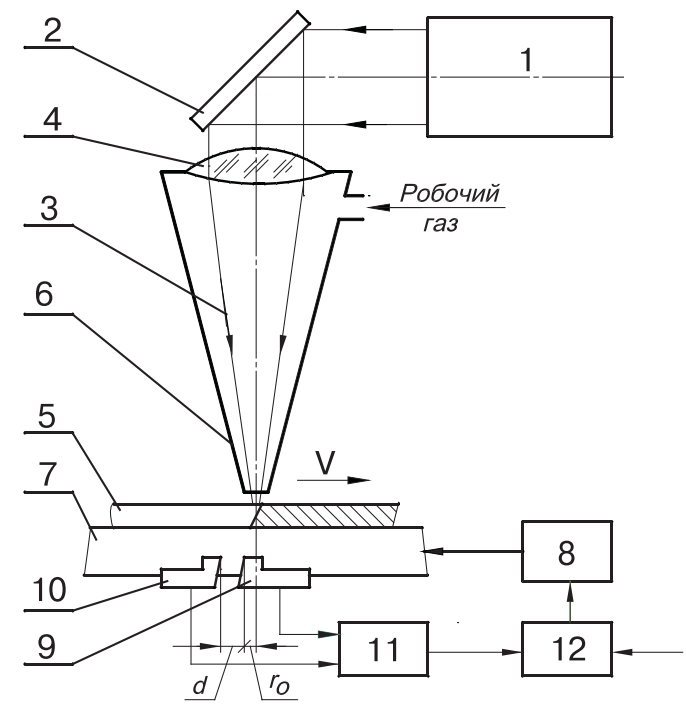

Рис. 1. Автоматизована установка для газолазерної різки прямолінійних ділянок металевих заготовок 
діаметру струменя робочого газу, що виходить з порожнини різу. Виходи обох датчиків через схему комутації 11 підключені до блоку управління 12 швидкістю приводу робочого столу, що дозволяє в автоматичному режимі регулювати швидкість різки. Блок управління 12 дозволяє також (у режимі налаштування) здійснювати ручне введення необхідної швидкості різки.

Запропонована установка працює таким чином. При оптимальній швидкості різки повне прорізання заготовки відбувається за час проходження лазерним променем відстані, рівної діаметру сфокусованого променя $2 \mathrm{r}_{0}$. Тобто заготовка прорізається наскрізь на відстані $r_{0}$ від осі установки в протилежному різці напрямку. При цьому струмінь робочого газу, що виходить 3 порожнини різу, проходить між датчиками тиску 9 і 10, не потрапляючи на жодний з них. Для швидкостей різки менших оптимальної швидкості повне прорізання закінчується на відстані меншій, ніж $r_{0}$. Отже, струмінь робочого газу, що виходить з порожнини різу, відхиляється від оптимального положення і потрапляє на датчик тиску 9. Датчик спрацьовує. У разі ж перевищення оптимальної величини швидкості різки повне прорізання заготовки не встигає статися за час проходження лазерним променем відстані рівної $2 r_{0}$. При цьому розрізання в нижніх шарах матеріалу відбувається без участі лазерної енергії, а тільки за рахунок нагрітого струменю робочого газу і продуктів руйнування, що виносяться цим струменем. Це веде до різкого зниження якості різки в нижніх шарах заготовки, а струмінь значно відхиляється від осі в протилежному до різки напрямку i, отже, викликає спрацьовування датчика тиску 10. Сигнали з датчиків тиску при їх спрацьовуванні поступають на вхід схеми комутації 11 , яка залежно від того, який з датчиків тиску (9 або 10) спрацював, видає відповідний імпульс керування на блок управління 12 швидкістю приводу 8 робочого столу 7. Це викличе зміну швидкості переміщення робочого столу, причому включення датчика тиску 9 веде до зростання швидкості руху столу і, навпаки, включення датчика 10 - до її зниження. При стабілізації процесу різки струмінь проходить між датчиками, не потрапляючи на жоден з них, а швидкість столу фіксується в оптимальному режимі.

Представлена установка має один істотний недолік. Вона застосовується лише для різки прямолінійних ділянок при розрізанні матеріалів.

Для усунення цього недоліку, тобто для реалізації можливості різки заготовок із складним контуром (у тому числі і з гострими кутами контура) автором запропонована наступна модернізація пристрою (рис. 2). Датчики тиску 9 і 10 розміщуються на масивному корпусі 11, який має тороїдальну форму з внутрішнім діаметром D і розташований безпосередньо під заготовкою, що розрізається, співвісно з лазерним променем та струменем робочого газу, тобто співвісно лазерному різаку. При цьому датчик 9 встановлюється на внутрішній циліндричній поверхні 
корпусу 11 (бажано як можна ближче до верхньої його кромки), а датчик 10 - на верхній поверхні корпусу, з самого внутрішнього краю. Зміна напряму різки не позначається на спрацьовуванні датчиків 9 і 10, оскільки вони розташовані суцільно по всьому периметру корпусу 11.

Виходи кожного з датчиків 9 і 10 через блок аналогово-цифрових перетворювачів 12 підключені до вхідного інтерфейсу комп'ютера 13, що управляє роботою лазерного комплексу. В нашому випадку комп'ютер 13 забезпечую також в процесі обробки в автоматичному режимі регулювання швидкості різки через свій вихідний інтерфейс і привід 8 робочого столу 7. Програмне забезпечення комп'ютера 13 дозволяє, крім цього, в режимі настроювання встановлювати оптимальні режими різки для певного матеріалу, певної товщини з урахуванням і інших параметрів, що впливають на протікання процесу різки.

Внутрішній діаметр корпусу 11, a, отже, і датчика 10 може бути розрахований по залежності

$$
D=2\left(r_{0}+d\right) \text {. }
$$

Для розрахунку діаметру D стосовно конкретної лазерної установки можна скористатися наступними міркуваннями. Діаметр плями фокусування може бути оцінений по відомій формулі [4]:

$$
\mathrm{d}_{0}=\mathrm{f} \theta \text {, }
$$

де $f-$ фокусна відстань фокусуючої лінзи; $\theta-$ кутове розходження лазерного променя, виміряне в радіанах.

Діаметр же струменя робочого газу d може бути прирівняний до діаметру вихідного отвору сопла для співвісної подачі газу.

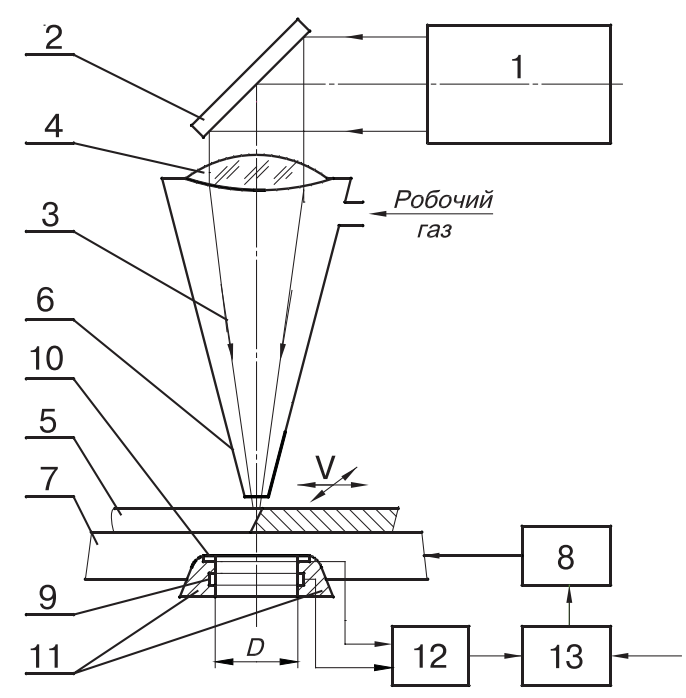

Рис. 2. Автоматизована установка для газолазерного вирізання деталей зі складним контуром 
При цьому деяке розходження струменя газу при проходженні через порожнину різу можна врахувати при налаштуванні чутливості спрацьовування датчи-ків тиску 9 і 10. Крім того, має місце відхилення струменя газу від вісі сопла при проходженні через порожнину різу в результаті нахилу поверхні різу по відношенню до цієї вісі. Проте таким відхиленням можна знехтувати через малість цього кута.

Величина зовнішнього діаметру верхньої кромки корпусу 11 не настільки важлива, але для поліпшення виходу струменя газу і продуктів руйнування з порожнини різу бажано, щоб ширина цієї кромки була якомога меншою. Крім того, корпус 11 може бути виконаний водоохолоджуваним.

Автором розглядався варіант розміщення датчика тиску 9 усередині корпусу 11 (аналогічно як в разі прямолінійної різки). При цьому датчик тиску 9 мав би круглу форми з діаметром $\mathrm{D}^{*}=$ $=2 r_{0}$. Розрахунки показали, що діаметр такого датчика був би в межах 0,2...0,5 мм, і такий датчик був би вельми уразливий до динамічної дії струменю робочого газу, а також високих температур. Тому такий варіант виявився неприйнятним.

Розміщення датчиків 9 і 10 під заготовкою, співвісно лазерному різаку має певні проблеми і обмеження. Так, при компановці лазерного технологічного комплексу, при якій робочий стіл із заготовкою $є$ нерухомим, а переміщується лазерний різак, значною проблемою стає в процесі різки здійснювати синхронне переміщення датчиків 9 і 10 співвісно з лазерним різаком. В той же час, досить часто реалізується компановка лазерного устаткування, коли лазерний різак - нерухомий, а стіл із заготовкою рухається по двох координатах. В даному випадку запропонована нами схема обробки сповна прийнятна.

В даному випадку особливості роботи пристрою полягають в наступному. При різці на оптимальних швидкостях струмінь відпрацьованого газу, що виходить 3 порожнини різу, постійно потрапляє на внутрішню циліндричну поверхню корпусу 11 , а, отже, на датчик тиску 9. При цьому включений стан датчика 9 сигналізує комп'ютеру 13 про оптимальні умови протікання процесу різки. Якщо ж швидкість різки змінюється і стає меншою оптимальної, то, як і в разі прямолінійного розрізання, струмінь газу, що виходить 3 порожнини різу, відхиляється від вихідного положення і переміщується у напрямі осі лазерного різака. Струмінь перестає потрапляти на датчик тиску 9, і останній спрацьовує на відключення. Комп'ютер 13 отримує інформацію про відхилення швидкості різки від оптимальної і плавно збільшує швидкість обробки, що веде, як результат, до відхилення струменя газу в напрямі від осі різака і її попаданню знову на датчик 9. Датчик 9 включається, а комп'ютер 13 стабілізує швидкість різки.

При перевищенні ж оптимальної величини швидкості різки струмінь газу відхиляється в напрямі від осі лазерного різака. При цьому струмінь потрапляє на датчик тиску 10, і датчик 10 
спрацьовує. Його включення (при включеному датчику 9 також) забезпечує (за допомогою комп'ютера 13) плавне зниження швидкості різки до досягнення оптимального значення. Процес різки знову стабілізується на оптимальній швидкості. При цьому датчик тиску 9 знаходитися у включеному стані, а датчик 10 - відключений.

Автоматизована установка для газолазерної різки матеріалів була зібрана на основі $\mathrm{CO}_{2}$ генератора потужністю в 1,5 кВт і розходженням лазерного променя $\theta=2,0$ мрад. Фокусування випромінювання здійснювалося лінзою з селеніду цинку з фокусною відстанню рівною $\mathrm{f}=127 \mathrm{~mm}$ в пляму діаметром приблизно в 0,25 мм. Як робочий газ застосовувався кисень тиском 2,0 атм, який витікав 3 сопла 3 вихідним отвором в 1,0 мм. Датчики тиску (сенсорного типу, із захисним термостійким покриттям) виготовлялися шириною приблизно в 0,5 мм. Мідний масивний корпус для розміщення датчиків тиску був виготовлений з внутрішнім діаметром рівним 2,25 мм, розрахованим по формулі (1) та зовнішнім - 5 мм. Корпус 3 датчиками орієнтувався співвісно соплу для подачі робочого газу, нижче на 8 мм базової поверхні для встановлення заготовки на робочому столі. За допомогою шини дротів датчики тиску через блок аналого-цифрових перетворювачів з'єднувалися 3 вхідним інтерфейсом комп'ютера, що управляв процесом різки за вказаним вище циклом.
Розроблена установка перевірялася на працездатність при розрізанні різних металевих матеріалів (конструкційна сталь, неіржавіюча сталь, титан) товщиною від 3 до 15 мм. Для кожного виду матеріалів і різної їх товщини оператором за допомогою комп'ютера встановлювалася оптимальна швидкість обробки. В процесі різки ця швидкість коректувалася як у бік збільшення, так і у бік зменшення, поки не встановлювалася на оптимальному значенні, тобто максимально можливою для якісного розрізання заданого матеріалу і товщини. При цьому якість отримуваних різів завжди була задовільною: шорсткість поверхні різу не вище $\mathrm{R}_{\mathrm{z}}=20$ мкм, грат на нижніх кромках був відсутній.

\section{Висновки}

1. На основі аналізу можливих технологічних схем газолазерної різки металевих матеріалів запропонована автоматизована установка такої обробки з високою якістю отримуваних різів, в якій оптимальне протікання процесу різки підтримується за рахунок контролю положення струменя робочого газу, який виходить (разом з продуктами руйнування) з порожнини різу.

2. Запропоновано два варіанти виконання автоматизованої високоякісної різки як для обробки прямолінійних ділянок, так і для реалізації можливості різки заготовок із складним контуром. Розглянуті теоретичні передумови для забезпечення інженерних розрахунків параме- 
трів вживаних датчиків для реалізації такої різки.

3. Описаний упроваджений варіант автоматизованої установки для газолазерної різки різноманітних металевих мате- ріалів (конструкційна сталь, неіржавіюча сталь, титан) різної товщини із заданою високою якістю кромок отримуваних різів при максимально можливій продуктивності обробки.

1. Григорьянц А. Г. Технические процессы лазерной обработки / А. Г. Григорьянц, И. Н. Шиганов, А. И. Мисюров. - М. : МГТУ им. Н. Э. Баумана, 2006. 2. Патент ГДР № 1079253 В23k 7/10, 1976 г. 3. А. с. СССР № 958060 В23k 26/00, 1982 г. 4. Коваленко В. С. Малоотходные процессы резки лучом лазера / В. С. Коваленко, В. В. Романенко, Л. М. Олещук. - Киев: Техника, 1987. - 112 с. 